\title{
Effects of photoperiod and feeding level on perirenal adipose tissue metabolic activity and leptin synthesis in the ovariectomized ewe
}

\author{
François Bocquier ${ }^{\mathrm{a}}$, Muriel Bonnet ${ }^{\mathrm{a}}$, Yannick Faulconnier ${ }^{\mathrm{a}}$, \\ Michèle Guerre-Millo ${ }^{\mathrm{b}}$, Patrice Martin ${ }^{\mathrm{c}}$, Yves Chilliarda*
}

\author{
${ }^{a}$ Laboratoire sous-nutrition des ruminants, Inra-Theix, 63122 Saint-Genès-Champanelle, France \\ b Inserm U465, Institut des Cordeliers, 75006 Paris, France \\ ${ }^{c}$ Laboratoire génétique biochimique et cytogénétique, Inra, 78350 Jouy-en-Josas, France
}

(Received 6 August 1998; accepted 27 October 1998)

\begin{abstract}
Leptin is secreted by adipose tissue and plays a pivotal role in regulating both body energy homeostasis and reproductive function in rodents. Among livestock, sheep is a seasonal breeder whose reproductive period is initiated by short daylength. We show that plasma leptin and leptin gene expression in perirenal adipose tissue were decreased when ovariectomized Lacaune ewes were exposed to short days ( 8 versus $16 \mathrm{~h} \mathrm{light/d}$ ). This effect of the photoperiod occurred despite the nutritional status, with leptin levels lower in underfed than in refed ewes, and without significant changes in perirenal fat mass and adipocyte size. Plasma prolactin and leptin followed a similar pattern suggesting a relationship between the two hormones. These findings indicate, for the first time, that adipose tissue leptin is modulated by daylength independently of food intake, body fatness and gonadal activity. Furthermore, plasma non-esterified fatty acids of underfed ewes subjected to short days were more elevated than for underfed ewes on long days. On the other hand, refed ewes placed under long daylength tended to have a higher adipose tissue lipogenic activity than refed ewes on short days. We propose that these adaptations of leptin production and lipogenic activity with long photoperiod are of physiological significance for body fat deposition, which naturally occurs during long days when food is abundant. Conversely, a low leptin level during short days may enhance the sensitivity to food deprivation during the natural reproductive season, where any food shortage would decrease plasma leptin under a threshold critical for reproduction. Furthermore, in this situation, the observed enhanced ability to mobilize body fat may be related to the necessity to cope with energy shortage. (C) Inra/Elsevier, Paris.
\end{abstract}

nutrition / photoperiod / adipose tissue / leptin / sheep

Résumé — Effets de la photopériode et du niveau alimentaire sur l'activité métabolique du tissu adipeux et sur la synthèse de leptine chez la brebis ovariectomisée. La leptine, hormone sécré-

\footnotetext{
* Correspondence and reprints

E-mail: chilliar@clermont.inra.fr
} 
tée par le tissu adipeux, joue un rôle central dans l'homéostase de l'énergie corporelle et dans la régulation de la reproduction chez les rongeurs. Parmi les herbivores domestiques, les ovins ont une reproduction saisonnée qui est stimulée par une photopériode courte. Nous montrons, chez la brebis Lacaune ovariectomisée, que le taux plasmatique de leptine, et l'expression du gène de la leptine par le tissu adipeux périrénal, sont diminués lorsque les brebis sont exposées aux jours courts (8 versus $16 \mathrm{~h} / \mathrm{j})$. L'effet de la durée du jour s'ajoute à celui de l'état nutritionnel. Le taux de leptine est en effet diminué chez les brebis sous-alimentées par rapport à celles qui sont réalimentées, et ceci sans qu'il ne se produise de modification ni de la masse, ni de la taille des adipocytes du tissu adipeux perirénal. La prolactine plasmatique et la leptine ont des réponses parallèles suggérant une relation entre ces deux hormones. Ces résultats indiquent, pour la première fois, que la production de leptine par le tissu adipeux est modulée directement par la photopériode, indépendamment des quantités ingérées, de l'état d'engraissement et de l'activité sexuelle. De plus, les acides gras non-estérifiés plasmatiques des brebis sous-alimentées placées en jours courts sont plus élevés que ceux des brebis sous-alimentées placées en jours longs. À l'inverse, lorsque les brebis réalimentées sont placées en jours longs, l'activité lipogénique du tissu adipeux tend à être accrue par rapport à celles qui sont en jours courts. Nous proposons que ces modulations de la sécrétion de leptine et de l'activité lipogénique du tissu adipeux avec l'accroissement de la durée du jour ont pour signification biologique de favoriser la reconstitution des réserves adipeuses, qui apparaît naturellement en jours longs lorsque les disponibilités alimentaires sont élevées. Inversement, des taux faibles de leptine en jours courts, pendant la période naturelle de reproduction, permettraient d'accroitre la sensibilité de cette fonction à la privation de nourriture. Ainsi, toute diminution des apports alimentaires ferait baisser le taux de leptine plasmatique au dessous d'un seuil critique pour la reproduction. De plus, dans cette situation, la capacité accrue à mobiliser des lipides corporels faciliterait l'adaptation à une pénurie alimentaire hivernale. (c) Inra/Elsevier, Paris.

nutrition / photopériode / tissu adipeux / leptine / ovin

\section{INTRODUCTION}

The ovine species is sensitive to daylength primarily for its reproduction, which is stimulated in autumn by decreasing daylength $[23,27]$ but also for food consumption which is maximum under long daylength $[17,19]$, together with body metabolic rate [37] and milk production [6]. The seasonal variations of daylength are accompanied by fluctuations of feed resources which are, in temperate climates, minimum during the winter and maximum in the spring and summer. The possibility that adipose tissue metabolism also varies with season has been suggested [36] but not yet fully demonstrated, mainly because food intake, which was not controlled in these experiments, may have varied along with season.

It has been shown in rodents that leptin, a hormone secreted by adipose tissue, is a powerful regulator of food intake and energy expenditure [28]. Moreover, leptin has a stimulatory action on reproduction $[1,2]$. This raises the hypothesis that the effects of photoperiod in sheep might be accounted for, at least in part, by a modulation of leptin production. To address this question, we measured the effects of two different light treatments (short versus long daylength exposure for 4 or 6 weeks) on plasma leptin and adipose tissue leptin gene expression of ewes subjected to either underfeeding or refeeding. Ewes were ovariectomized in order to prevent any change in cyclic activity that could be driven by the photoperiod. In addition, to avoid any indirect effects of photoperiod on adipose tissue metabolism that could be due to changes in food intake, ewes were given fixed amounts of food within each feeding treatment. Changes in blood metabolites, hormones and adipose tissue lipogenic enzyme activities, were also measured in order to assess the specificity of the leptin response. 


\section{MATERIALS AND METHODS}

\subsection{Animals and treatments}

Twenty adult ovariectomized Lacaune ewes were placed, during a 3-week pre-experimental period, in individual pens with a controlled food intake corresponding to $123( \pm 2) \%$ of their energy requirements calculated [4] on the basis of $0.4 \mathrm{MJ}$ metabolizable energy $/ \mathrm{d} / \mathrm{kg}$ (body weight $)^{0.75}$. Thereafter ewes were arranged, according to their body weight and body condition score (a score related to the subcutaneous fat thickness), in a $2 \times 2$ factorial design (five ewes per treatment) in which both the level of feeding (underfeeding versus refeeding) and the daylength (short versus long) were controlled. Light treatments started in January (natural light period of approximately $9 \mathrm{~h} / \mathrm{d}$ ), and ewes were subjected to either short ( $8 \mathrm{~h}$ light/d) or long ( $16 \mathrm{~h}$ light/d) daylength for 3 weeks. In the short day treatment, light was switched on at $8 \mathrm{a} . \mathrm{m}$. and switched off at 4 p.m., while long days started at 4 a.m. and finished at 8 p.m. All ewes were then given a restricted amount of food corresponding to $22( \pm 1) \%$ of their energy requirements for $7 \mathrm{~d}$. Thereafter half of them were slaughtered (9-10 a.m.) while the remaining ewes were refed (pair-feeding according to actual feed intake across photoperiodic treatments) for $14 \mathrm{~d}$ until slaughter, when their level of intake met $190( \pm 2) \%$ of their energy requirements. During both the pre-experimental period and the period of restricted feeding ewes were fed once a day (10 a.m.), while they were fed equal meals twice a day (10 a.m. and 3 p.m.) during the refeeding period. All experimental procedures involving the use of animals were conducted after approval by the Animal Care and Use Committee of Inra.

\subsection{Plasma measurements}

Blood samples were taken from the jugular vein during the pre-experimental period and the day before slaughter, at 2 p.m. for the determination of plasma leptin, insulin and metabolites. Immunoreactive leptin was assayed with a RIA kit ('Multispecies' kit; Linco Research) with a sensitivity of $0.5 \mathrm{ng} / \mathrm{mL}$ and intra- and interassay coefficients of variation (CV) of 4 and $8 \%$, respectively. Insulin was determined with a RIA kit (INSI-PR RIA kit, CIS bio international) with a sensitivity of $4 \mu \mathrm{IU}$, and intra- and inter-assay $\mathrm{CV}$ of 9 and $13 \%$, respectively. All metabolites were determined with an ELAN auto-analyser (Merck-Clévenot SA, France) by enzymatic assays. Non-esterified fatty acids (NEFA) were analysed [8] with a Wako-Unipath NEFA-C kit (ref. 46551). Beta-hydroxybutyrate (3-OHbutyrate) was analysed [3] with the $3-\mathrm{OH}-$ butyrate dehydrogenase method (Boehringer ref. 127841). Glucose was analysed with the glucose-dehydrogenase method (Glucose S, Merck System 100). Lactate was analysed with the BioMérieux lactate PAP kit (ref. 61192). Urea was analysed with the Merk diagnostic kit (1.19702.0001). Triglycerides were analysed with the Biotrol kit (SFBC:KG). Free glycerol was analysed with the glycerol kinase method (Sigma kit, ref. 37-A). Acetate was analysed with the Boehringer Mannheim kit (ref. 148261). In addition, blood was sampled serially (every 20 min for $6 \mathrm{~h}$ ) for the analysis of ovine prolactin overall mean, baseline, spike amplitude and pulsatility, by RIA as previously described [5], with a sensitivity of $0.15 \mathrm{ng} / \mathrm{mL}$, and intra- and interassay $\mathrm{CV}$ of 6 and $9 \%$, respectively.

\subsection{Adipose tissue measurements}

Perirenal adipose tissue samples were fixed in osmium tetroxide prior to adipose cell size determination [30], or stored at $-80^{\circ} \mathrm{C}$ pending measurement [9] of the activity of four lipogenic enzymes ((fatty acid synthase (FAS), glucose6-P-dehydrogenase (G6PDH), malic enzyme, and glycerol-3-P-dehydrogenase (G3PDH)), and RNA extraction [7]. Ovine leptin mRNA was determined by RT-PCR, using the mRNA from a housekeeping gene (cyclophilin) as a control. cDNA was synthesized by extension of oligo (dT) primer from $4 \mu \mathrm{g}$ total RNA using $100 \mathrm{U}$ of SuperScript reverse transcriptase (Gibco BRLLife Technologies). After RNA degradation by RNAse treatment (Boehringer Mannheim), either 28 or 40 cycles of PCR were performed for cyclophilin or leptin amplification, respectively, using $1 \mathrm{U}$ of Taq polymerase (Promega). Leptin specific primers were chosen in the leptin cDNA sequences conserved between species, determined from homology searches using nucleic acid databases (GenBank and EMBL) and software package GCG [14]. The leptin DNA fragment $(220 \mathrm{pb})$ yielded after PCR was sequenced; it was $75 \%$ homologous with the sequence for the human species in the data banks. The PCR products were fractionated in a $3 \%$ agarose gel and visualized by ethidium bromide staining. 


\subsection{Statistical analysis}

Data were analysed by a two-way variance analysis (taking into account the effects of feeding, photoperiod and interaction). Mean plasma measurements were adjusted with covariates obtained during the pre-experimental period, when significant.

\section{RESULTS}

\subsection{Leptin changes}

As shown in figure $1 \mathrm{~A}$, plasma leptin concentration was reduced $(-19 \% ; P<0.03)$ in the ewes exposed to short days, compared to those exposed to long days, and it was lower in underfed $(-24 \% ; P<0.01)$ compared to refed ewes. In perirenal adipose tissue, the leptin mRNA level (figure $1 B$ ) was also decreased by short days $(-40 \%$; $P<0.03)$ and lower in underfed ewes $(-31 \%)$, although this latter effect did not reach significance $(P<0.09)$.

\subsection{Plasma metabolites and hormones}

Both plasma insulin (-64\%; figure 1C) and prolactin $(-45 \%$; figure $1 D)$ were lower in underfed ewes, although only prolactin was changed by the photoperiod, with a decrease under short days ( $-62 \%$ in short versus long days; figure $1 D$ ). Plasma metabolites of underfed ewes, compared to refed ewes, were significantly $(P<0.05)$ lower for glucose $(-12 \%)$, lactate $(-34 \%)$, acetate $(-76 \%), 3-\mathrm{OH}$-butyrate $(-21 \%)$, triglycerides $(-43 \%)$ and urea $(-68 \%)$, and higher for free glycerol $(+12 \%$ ) (table $I)$ and NEFA (+ $1190 \%$; figure 2A). Plasma metabolite levels were unaffected by the length of the photoperiod (table I), except for NEFA that were significantly $(P<0.05)$ increased $(+41 \%)$ by short days in underfed ewes (figure $2 A$ ).

\subsection{Adipose tissue characteristics}

None of the treatments affected the perirenal adipose tissue weight and mean fat cell volume (table I). There was, however, a non-significant increase in body weight during refeeding that was due to the well known [10] effect of feeding level on digestive contents in ruminants. Lipogenic enzyme activities (figure 2 and table I) were lower in underfed than in refed ewes (FAS: $-79 \%$, malic enzyme: $-54 \%$; G3PDH: $-50 \%$ and G6PDH: $-74 \%$ ). Effects were similar when activities were expressed per cell (figure 2 and table I) or per gram fat tissue (results not shown). Furthermore, malic enzyme activity was significantly $(P<0.05)$ increased in adipose tissues of ewes subjected to long photoperiod (figure $2 C$ ), and the response was higher in refed ewes. This positive effect of long daylength seems also to appear in overfed ewes for three other lipogenic enzymes, but these trends were non-significant (figure 2 and table I).

\section{DISCUSSION}

\subsection{Leptin and prolactin changes}

The plasma leptin concentrations in the present ewes were in the lower range of values that were observed in non-obese humans [13]. This could result either from ovariectomy of ewes [32], or from an underestimation by immunoreactive leptin of the total plasma leptin in ovine species.

The lower plasma leptin concentration of underfed ewes, compared to refed ewes, is in agreement with previous observations in rodents [1] and cattle [11]. It is noteworthy that the negative effect of short days, when compared to long days, occurred in both nutritional situations. The effects of both the photoperiod and the feeding level were also apparent on adipose tissue leptin mRNA, in agreement with results of the effect of feeding level in rats [31]. This indicates that regulation of leptin gene expres- 

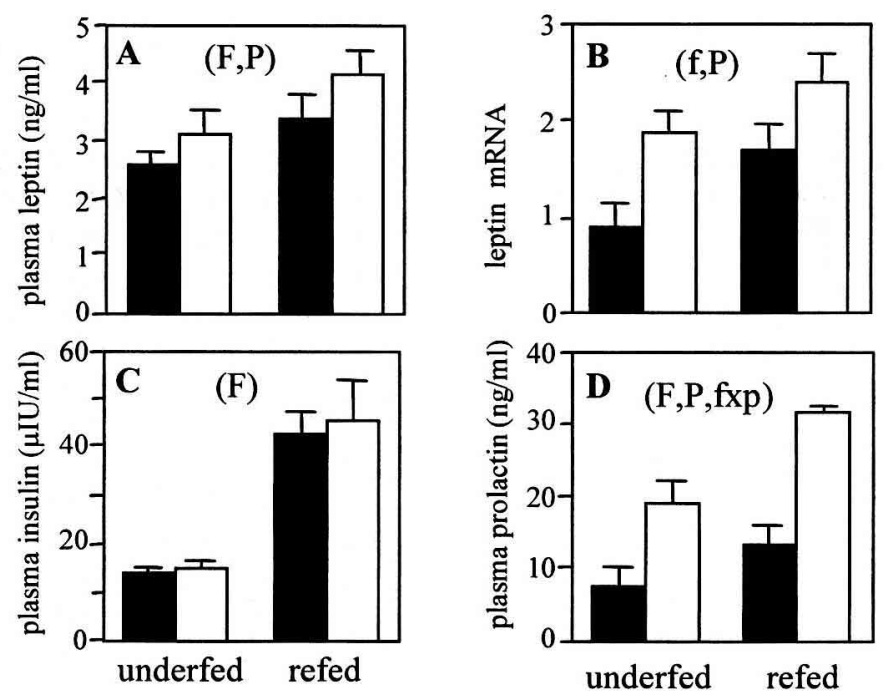

Figure 1. Effects of daylength (shaded bars: short days ( $8 \mathrm{~h} / \mathrm{d})$ and open bars: long days $(16 \mathrm{~h} / \mathrm{d})$ ) and nutritional status (underfed ( $22 \%$ ) or refed (190\% of energy requirements)) on (A) plasma leptin, (B) adipose tissue leptin mRNA (in arbitrary units), (C) plasma insulin and (D) overall mean plasma prolactin (five ewes per group, mean $\pm S E M$ ). F, P or $f$, p: significant effect of feeding level and photoperiod $(P<0.05$ or $P<0.10$, respectively); $\mathrm{f} \times \mathrm{p}$ : significant interaction $(P<0.10)$.

Table I. Effects of nutritional status and daylength on perirenal adipose tissue characteristics, and plasma metabolites (five ewes per group).

\begin{tabular}{|c|c|c|c|c|}
\hline \multirow{2}{*}{$\begin{array}{l}\text { Nutritional status }{ }^{1} \\
\text { Daylength }^{2}\end{array}$} & \multicolumn{2}{|c|}{ Underfed } & \multicolumn{2}{|c|}{ Refed } \\
\hline & Short & Long & Short & Long \\
\hline $\begin{array}{l}\text { Energy intake }(\mathrm{MJ} \mathrm{ME} / \mathrm{d})^{3} \\
\text { Body weight }(\mathrm{kg})\end{array}$ & $\begin{aligned} 2.1 & \pm 0.1^{\mathrm{a}} \\
71.1 & \pm 1.9\end{aligned}$ & $\begin{array}{l}2.2 \pm 0.1^{\mathrm{a}} \\
71.6 \pm 3.2\end{array}$ & $\begin{array}{l}17.2 \pm 0.7^{b} \\
76.1 \pm 2.2\end{array}$ & $\begin{array}{l}17.2 \pm 0.7^{b} \\
74.9 \pm 4.3\end{array}$ \\
\hline $\begin{array}{l}\text { Perirenal adipose tissue } \\
\text { Mass (kg) } \\
\text { Adipocyte volume (pl) } \\
\text { G6PDH }^{4}\end{array}$ & $\begin{array}{l}2.31 \pm 0.17 \\
935 \pm 76 \\
149 \pm 13^{\mathrm{a}}\end{array}$ & $\begin{array}{l}2.14 \pm 0.25 \\
843 \pm 38 \\
146 \pm 18^{a}\end{array}$ & $\begin{array}{l}2.40 \pm 0.27 \\
712 \pm 77 \\
547 \pm 32^{b}\end{array}$ & $\begin{array}{l}2.26 \pm 0.43 \\
867 \pm 149 \\
575 \pm 119^{b}\end{array}$ \\
\hline $\begin{array}{l}\text { Plasma metabolites } \\
\text { Glucose }(\mathrm{mM}) \\
\text { 3-OH-butyrate }(\mathrm{mM}) \\
\text { Lactate }(\mathrm{mM}) \\
\text { Acetate }(\mu \mathrm{M}) \\
\text { Glycerol }(\mu \mathrm{M}) \\
\text { Triglycerides }(\mu \mathrm{M}) \\
\text { Urea }(\mathrm{g} / \mathrm{L})\end{array}$ & $\begin{aligned} 3.21 & \pm 0.11^{\mathrm{a}} \\
0.44 & \pm 0.04 \\
0.72 & \pm 0.06^{\mathrm{ab}} \\
115 & \pm 22^{\mathrm{a}} \\
139 & \pm 8^{\mathrm{a}} \\
83 & \pm 12^{\mathrm{ab}} \\
0.15 & \pm 0.01^{\mathrm{a}}\end{aligned}$ & $\begin{aligned} 3.15 & \pm 0.11^{\mathrm{a}} \\
0.47 & \pm 0.07 \\
0.57 & \pm 0.07^{\mathrm{b}} \\
201 & \pm 32^{\mathrm{a}} \\
124 & \pm 3^{\mathrm{ab}} \\
49 & \pm 4^{\mathrm{b}} \\
0.16 & \pm 0.02^{\mathrm{a}}\end{aligned}$ & $\begin{array}{l}3.88 \pm 0.06^{\mathrm{b}} \\
0.55 \pm 0.05 \\
1.15 \pm 0.21^{\mathrm{a}} \\
607 \pm 54^{\mathrm{b}} \\
114 \pm 3^{\mathrm{b}} \\
122 \pm 24^{\mathrm{a}} \\
0.49 \pm 0.05^{\mathrm{b}}\end{array}$ & $\begin{array}{l}3.50 \pm 0.22^{\mathrm{ab}} \\
0.60 \pm 0.04 \\
0.79 \pm 0.16^{\mathrm{ab}} \\
720 \pm 53^{\mathrm{b}} \\
122 \pm 6^{\mathrm{ab}} \\
113 \pm 18^{\mathrm{a}} \\
0.49 \pm 0.03^{\mathrm{b}}\end{array}$ \\
\hline
\end{tabular}

${ }^{1}$ Underfed or refed, i.e. 22 or $190 \%$ of maintenance requirements, respectively.

2 Short $=8 \mathrm{~h} / \mathrm{d}$ light; long $=16 \mathrm{~h} / \mathrm{d}$ light.

3 Recorded during the $2 \mathrm{~d}$ before slaughtering. ME: Metabolizable energy.

${ }^{4}$ Glucose-6-phosphate dehydrogenase ( $\mathrm{nmol} / \mathrm{min} / 10^{6}$ adipocytes).

Means ( \pm SEM) which share a different superscript are statistically different $(P<0.05)$. 

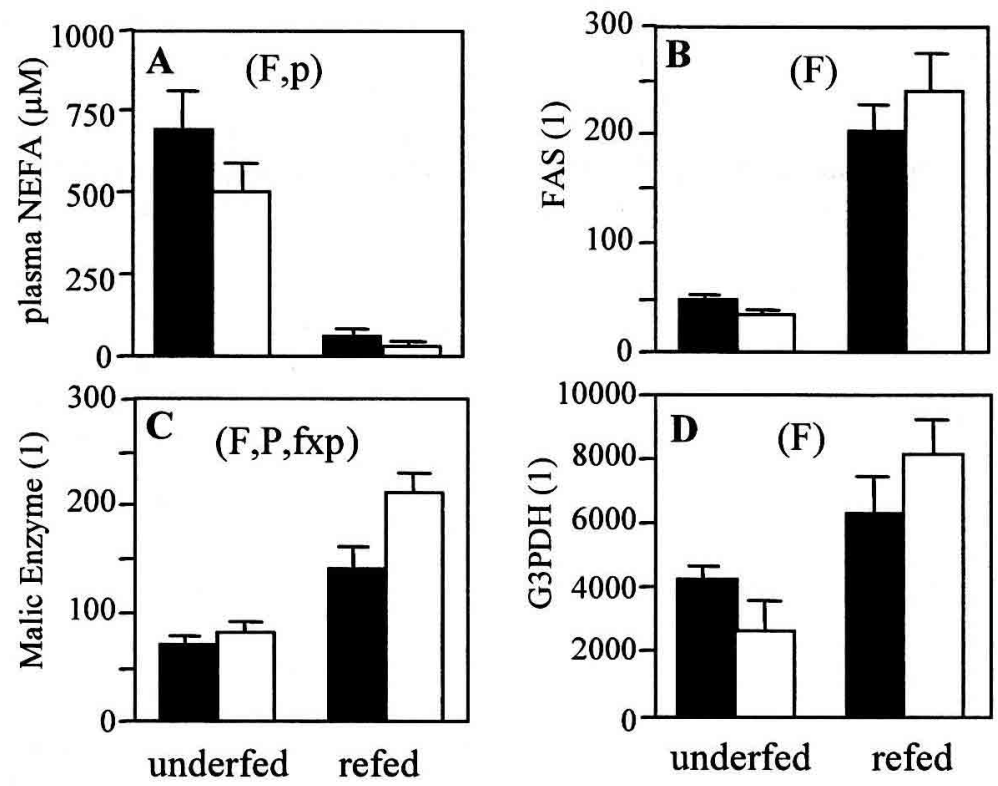

Figure 2. Effects of daylength (shaded bars: short days $(8 \mathrm{~h} / \mathrm{d})$ and open bars: long days $(16 \mathrm{~h} / \mathrm{d})$ ) and nutritional status (underfed (22\%) or refed (190\% of energy requirements)) on (A) plasma nonesterified fatty acids, and on adipose tissue, (B) fatty acid synthase, (C) malic enzyme and (D) glycerol-3-phosphate dehydrogenase activities: (1) $\mathrm{nmol} / \mathrm{min} / 10^{6}$ adipocytes (five ewes per group, mean \pm SEM). F, P or f, p: significant effect of feeding level and photoperiod $(P<0.05$ or $P<0.10$, respectively); $\mathrm{f} \times \mathrm{p}$ : significant interaction $(P<0.10)$.

sion occurred, at least in part, at a pretranslational level. It has been previously shown in sheep $[5,27,36]$ that plasma prolactin is very sensitive to photoperiod and to feeding level [5]. The results in the present experiment are in good agreement with these previous observations: plasma prolactin was decreased by short days and by underfeeding. The similarity in the pattern of variations of overall mean plasma prolactin and plasma leptin at 2 p.m., according to experimental treatments, is striking (figure $1 A$, $D$ ). In view of recent data [38] indicating that leptin acutely stimulates in vitro prolactin release by rat pituitary, our results suggest that the photoperiod and feedinginduced changes in prolactin could be driven, at least in part, by leptin. Future studies on diurnal rhythm of plasma leptin [29] in sheep could help to better understand this putative relationship.

\subsection{Direct effect of photoperiod on adipose tissue leptin synthesis}

The fact that the effect of photoperiod on leptin was shown in ewes consuming strictly the same amount of food suggests that this effect is not due to nutritional factors. Furthermore, the effect of photoperiod on leptin in sheep was not associated with changes in other factors known to alter leptin production in rodents, human and cattle. Hence, it is established that plasma leptin is positively related to body fatness (in rodents: [18], in humans: [13] and in cows: [11]). In the present study, owing to their 
short duration (i.e. less than 2 weeks), experimental treatments neither affected the perirenal adipose tissue mass, nor mean cell volume (table I). Since the weight of perirenal depot is a good estimate of total fat mass in ewes ( $r=+0.91$ [33]), this suggests that observed changes in leptin levels were not elicited by changes in adiposity.

The variations in plasma metabolites and hormones due to changes in feeding level are in agreement with observed responses in underfed-refed ruminants [10]. Insulin and glucose are potential regulators of leptin gene expression in rodents [25,31]. Here, insulinaemia (figure 1) and glycaemia (table I) were decreased by underfeeding but not significantly changed by photoperiod. This makes it unlikely that these factors are involved in the effects of daylength. The absence of photoperiod-induced changes in all other plasma metabolites (table $I$ ) except NEFA (figure 2) indicates that the effects of photoperiod on plasma leptin and on adipose tissue leptin mRNA are probably not due to changes in intermediary metabolism.

It was reported that photoperiod changed adipose tissue leptin mRNA in Djungarian hamsters [20]. Similar to our observations, short days decreased leptin gene expression. However, in this model, food consumption was not controlled. Furthermore, adipose tissue mass and gonadal activity, which have been shown to modulate leptin production in rats and humans [32], were sharply decreased along with leptin mRNA [20]. Unless strictly controlled feeding conditions and a castrated hamster model are used, similar to our study, no direct role may be attributed to daylength.

\subsection{Effects of photoperiod on adipose tissue lipogenesis and mobilization}

The activity of adipose tissue lipogenic enzymes was (malic enzyme) or tended to be (FAS, G3PDH and G6PDH) increased by long daylength in refed ewes. This was not apparent in underfed ewes, whose adipose tissue lipogenic activity is very low. Significant effects of photoperiod on adipose tissue lipoprotein lipase activity and mRNA were also observed (M. Bonnet et al., unpublished results). These effects of photoperiod were not driven by nutrient supply, since food intake was kept identical between the groups of ewes. This could reflect an enhanced ability of adipose tissue to deposit fat during long-day periods of the year, when food is highly available. Such a result is in agreement with observations made under natural daylight conditions in sheep [36]. These authors observed that the rate of fatty acid synthesis and lipoprotein lipase activity were increased 5.8 and 2.3 folds, respectively, between October and May. This was, however, probably related in part to an increment of food intake since plasma insulin, glucose and acetate were also increased between October and May $(+44,+18$ and $+23 \%$, respectively). Our results further demonstrate that lipogenic activity can be enhanced directly by long daylength.

An effect of the photoperiod was observed on plasma NEFA, which were increased in the underfed ewes adapted to short daylength. This has not been reported so far, and could reflect an enhanced mobilization of body fat when underfeeding occurs during short days, which naturally occurs during the winter.

\subsection{General discussion and conclusions}

This work gives evidence that, depending on feeding level, the photoperiod affects either adipose tissue mobilization or, less markedly, lipogenic activity. Furthermore plasma leptin and adipose tissue leptin mRNA are modulated both by photoperiod and feeding level.

In the Siberian hamster [24], exposure to short days increased norepinephrine turnover. A similar effect, which remains 
to be demonstrated in sheep, could account for an increase in plasma NEFA, as well as for decreases in adipose tissue leptin and lipogenic activities. Indeed, beta-adrenergic agents lowered leptin gene expression and plasma level in rodents [35] and cattle [12]. In refed ewes, however, shortening daylength decreased leptin level without any significant effect on plasma NEFA, which are known to be sensitive to betaadrenergic agents in sheep [34] and in overfed cattle [16]. This indicates that the effect of the short-day photoperiod on leptin is probably not mediated uniquely through beta-adrenergic pathways in sheep, or that adipose tissue leptin synthesis is more sensitive to beta-agonists than is lipolysis.

The mechanisms through which photoperiod influences adipose tissue leptin remain unknown. As short days increase the nocturnal release of the pineal melatonin, it is possible that melatonin secretory pattern modulates leptin gene expression and/or secretion. Interestingly enough, peripheral effects of melatonin are plausible, since specific binding sites have been recently described in Siberian hamster brown adipose tissue [22]. Other mediators could be involved, since it has been shown recently [15] that an iv injection of neuropeptide $Y$ increased leptin mRNA level in ovine adipose tissue. It was also shown that glucocorticoids could modulate leptin in rats [26] and humans [21]; however, cortisol did not change in sheep between October and May [36].

Our study shows that short days decrease plasma leptin and down-regulate adipose tissue leptin gene expression, regardless of changes in food supply and at constant body fatness and gonadal activity. Leptin might act as a chronic metabolic signal to the reproductive system, by indicating the level of fat stores available to meet the caloric demands of reproduction. In addition, it has been suggested [1] that in mice a transiently insufficient nutrient supply would be acutely signalled to the neuroendocrine and repro- ductive systems by lowering plasma leptin. In ewes, the modulation of leptin levels by photoperiod could play a role in the physiological adaptation to environmental constraints. In short days, a low basal level of leptin could increase the sensitivity to shortage of feed resources that would further decrease plasma leptin below a threshold, critical for the reproductive processes.

The enhanced responsiveness of adipose tissue mobilization during short photoperiod may be of adaptive value to cope with winter shortage of food. Furthermore, in long days, out of the reproductive period, high leptin levels may be associated with a lower sensitivity of the central mechanism by which leptin regulates appetite [13]. This adaptation, coupled to a trend towards a higher adipose tissue lipogenic activity for a given level of food intake, would facilitate the replenishment of body reserves during the period of high food availability.

\section{ACKNOWLEDGEMENT}

We thank J. Fléchet, A. Ollier, R. Lefaivre, M. Tourret and C. Giraud-Delville for technical assistance, A. Combeau and D. Roux for animal care, and C. Leroux and G. Kann for advice during PCR and prolactin measurements, respectively. This work was supported by the Inra Programme 'Lipogenesis in farm animals'.

\section{REFERENCES}

[1] Ahima R.S., Prabakaran D., Mantzoros C., Qu D., Lowell B., Maratos-Flier E., Flier J.S., Role of leptin in the neuroendocrine response to fasting, Nature 382 (1996) 250-252.

[2] Barash I.A., Cheung C.C., Weigle D.S., Ren H., Kabigting E.B., Kuijper J.L., Clifton D.K., Steiner R.A., Leptin is a metabolic signal to the reproductive system, Endocrinology 137 (1996) 3144-3147.

[3] Barnouin J., El Idilbi N.E., Chilliard Y., Chacornac J.P., Lefaivre R., Micro-dosage automatisé sans déprotéinisation du 3-hydroxybutyrate plasmatique chez les bovins, Ann. Rech. Vét. 17 (1986) 129-139. 
[4] Bocquier F., Thériez M., Sheep in ruminant nutrition, in: Jarrige R. (Ed.), Ruminant Nutrition: Recommended Allowances and Feed Tables, Inra Publications, John Libbey Eurotex, 1990, pp. 153-165.

[5] Bocquier F., Kann G., Thériez M., Relationships between secretory patterns of growth hormone, prolactin and body reserves and milk yield in dairy ewes under different photoperiod and feeding conditions, Anim. Prod. 51 (1990) 115-125.

[6] Bocquier F., Ligios S., Molle G., Casu S., Effets de la photopériode sur la production, la composition du lait et sur les consommations volontaires chez la brebis laitière, Ann. Zootech., 46 (1997) 427-438.

[7] Bonnet M., Faulconnier Y., Fléchet J., Hocquette J.F., Leroux C., Langin D., Martin P., Chilliard Y., Messenger RNAs encoding lipoprotein lipase, fatty acid synthase and hormone-sensitive lipase in the adipose tissue of underfed-refed ewes and cows, Reprod. Nutr. Dev. 38 (1998) 297-307.

[8] Chilliard Y., Bauchart D., Barnouin J., Determination of plasma non-esterified fatty acids in herbivores and man: a comparison of values obtained by manual or automatic, chromatographic, titrimetric, colorimetric and enzymatic methods, Reprod. Nutr. Dev. 24 (1984) 469-482.

[9] Chilliard Y., Gagliostro G., Fléchet J., Lefaivre J., Sebastian I., Duodenal rapeseed oil infusion in early and midlactation cows. 5. Milk fatty acids and adipose tissue lipogenic activities, J. Dairy Sci. 74 (1991) 1844-1854.

[10] Chilliard Y., Doreau M., Bocquier F., Lobley G.E., Digestive and metabolic adaptations of ruminants to variations in food supply, in: Journet $M$. Grenet E., Farce M.H., Thériez M., Demarquilly C. (Eds.), Recent Developments in the Nutrition of Herbivores, Inra Publications, Paris, 1995, pp. 329-360.

[11] Chilliard Y., Ferlay A., Delavaud C., Bocquier F., Plasma leptin in underfed or refed adult $\mathrm{Hol}-$ stein and Charolais cows, and its relationship with adipose tissue cellularity, 8th Int. Cong. Obesity, Paris, 29 August-3 September, Int. J. Obesity (1998) 22 (suppl. 3) S171.

[12] Chilliard Y., Ferlay A., Delavaud C., Bocquier F., Effects of infusion of non-selective beta-, or selective betal - or beta2-adrenergic agonists on plasma immunoreactive leptin in cattle, 3rd Int. Conf. on Farm Anim. Endocrinol. 7-10 December, Brussels, Belgium, 1998, in press.

[13] Considine R.V., Sinha M.K., Heiman M.L., Kriauciunas A., Stephens T.W., Nyce M.R., Ohannesian J.P., Marco C.C., Mc Kee L.J., Bauer T.L., Caro J.F., Serum immunoreactive-leptin concentrations in normal-weight and obese humans, N. Engl. J. Med. 334 (1996) 292-295.

[14] Devereux J., Haeberli P., Smithies 0., A competitive set of sequence analyse programmes for the VAX, Nucleic Acid Res. 12 (1984) 387-395.
[15] Dyer C.J., Simmons J.M., Matteri R.L., Keisler D.H., Effects of an intravenous injection of NPY on the leptin and NPY-Y1 receptors mRNA expression in ovine adipose tissue, Domest. Anim. Endocrinol. 14 (1997) 325-333.

[16] Ferlay A., Chilliard Y., Sala A.M., Durier C., Bocquier F., Somatotropin treatment does not affect nonesterified fatty acid response to adrenergic injections in underfed or overfed nonlactating cows, J. Nutr. 126 (1996) 945-954.

[17] Gordon J.G., Effect of time of the year on the roughage intake of housed sheep, Nature 204 (1964) 798-799.

[18] Houseknecht K.L., Baile C.A., Matteri R.L., Spurlock M.E., The biology of leptin: a review, J. Anim. Sci. 76 (1998) 1405-1420.

[19] Kay R.N.B., Seasonal changes of appetite in deer and sheep, ARC Res. Rev. 5 (1979) 13-15.

[20] Klingenspor M., Dickopp A., Heldmaier G., Klaus S., Short photoperiod reduces leptin gene expression in white and brown adipose tissue of Djungarian hamsters, FEBS Lett, 399 (1996) 290-294.

[21] Larsson H., Ahrén B., Short-term dexamethasone treatment increases plasma leptin independently of changes in insulin sensitivity in healthy women, J. Clin. Endocrinol. Metab. 81 (1996) 4428-4432.

[22] Le Gouic S., Atgié C., Viguerie-Bascands N., Hanoun N., Larrouy D., Ambid L., Raimbault S., Ricquier D.P., Gardiola-Lemaitre B., Pénicaud L., Casteilla L., Characterisation of a melatonin binding site in Siberian hamster brown adipose tissue, Eur. J. Pharmacol. 339 (1997) 27!-278.

[23] Malpaux B., Viguié C., Thièry J.C., Chemineau P., Contrôle photopériodique de la reproduction, Inra Prod Anim 9 (1996) 9-23.

[24] McElroy J., Mason P., Hamilton J., Wade G., Effects of diets and photoperiod on NE and GDP binding in Siberian hamster brown adipose tissue, Am. J. Physiol. 250 (1986) R383-388.

[25] Mizuno T., Bergen H., Kleopoulos S., Bauman W.A., Mobbs C.V., Effect of nutritional status and ageing on leptin gene expression in mice: importance of glucose, Horm. Metab. Res. 28 (1996) 679-684.

[26] Murakami T., Iida M., Shima K., Dexamethasone regulates obese gene expression in isolated rat adipocytes, Biochem. Biophys. Res. Comm. 214 (1995) 1260-1267.

[27] Ortavant R., Bocquier F., Pelletier J.P., Ravault J.P., Thimonier J., Volland-Nail P., Seasonality of reproduction in sheep and its control by photoperiod, Austr. J. Biol. Sci. 41 (1988) 69-85.

[28] Pelleymounter M.A., Cullen M.J., Baker M.B., Hecht R., Winters D., Boone T., Collins F., Effects of the obese gene product on body weight regulation in ob/ob Mice, Science 269 (1995) 540-543. 
[29] Pickavance L., Tadayyon M., Williams G., Vernon R.G., Lactation suppresses diurnal rhythm of serum leptin, Biochem. Biophys. Res. Comm. 248 (1998) 196-199.

[30] Robelin J., Cellularity of bovine adipose tissues: developmental changes from 15 to 65 percent mature weight, J. Lipid Res. 22 (1981) 452-457.

[31] Saladin R., De Vos P., Guerre-Millo M., Leturque A., Girard J., Staels B., Auwerx J., Transient increase in obese gene expression after food intake or insulin administration, Nature 377 (1995) 527-529.

[32] Shimizu H., Shimomura Y., Nakanishi Y., Futawatari T., Ohtani K., Sato N., Mori M., Estrogen increases in vivo leptin production in rats and human subjects, J. Endocr. 154 (1997) 285-292.

[33] Teixeira A., Delfa R., Colomer-Rocher F., Relationships between fat depots and body condition score or tail fatness in the Rasa Aragonesa breed, Anim. Prod. 49 (1989) 275-280.

[34] Thomton R.F., Tume R.K., Payne G., Larsen T.W., Johnson G.W., Hohenhaus M.A., The influence of the beta- 2 adrenergic agonist, clenbuterol, on lipid metabolism and carcass composition in sheep, Proc. New Zealand Soc. Anim. Prod. 45 (1985) 97-101.

[35] Trayhurn P., Duncan J.S., Rayner D.V., Acute cold-induced suppression of ob (obese) gene expression in white adipose tissue of mice: mediation by the sympathetic system, Biochem. J. 311 (1995) 729-733.

[36] Vernon R.G., Clegg R.A., Flint D.J., Adipose tissue metabolism in sheep: response to season and its modulation by reproductive state, Horm. Metabol. Res. 18 (1986) 308-312.

[37] Walker V. A, Young B.A., Walker B., Does seasonal photoperiod directly influence energy metabolism?, in: Week C., Boessinger M. (Eds.), Energy Metabolism of Farm Animals, Eur. Ass. Anim. Prod. 58 (1991) 372-375.

[38] Yu W.H., Kimura M., Walczewska A., Karanth S., McCann S.M., Role of leptin in hypothalamicpituitary function, Proc. Natl. Acad. Sci. 94 (1997) 1023-1028. 